Revue d'histoire de l'Amérique française

REYUE D.HISTOIRE DE L'AMÉRIQUE FRANÇAISE

\title{
AUBIN, Paul et Louis-Marie CÔTÉ, Bibliographie de l'histoire du Québec et du Canada, 1946-1965. Québec, Institut québécois de recherche sur la culture, 1987. Tomes 1 et 2.
}

\section{Richard Jones}

Volume 41, numéro 2, automne 1987

URI : https://id.erudit.org/iderudit/304573ar

DOI : https://doi.org/10.7202/304573ar

Aller au sommaire du numéro

Éditeur(s)

Institut d'histoire de l'Amérique française

ISSN

0035-2357 (imprimé)

1492-1383 (numérique)

Découvrir la revue

Citer ce compte rendu

Jones, R. (1987). Compte rendu de [AUBIN, Paul et Louis-Marie CÔTÉ,

Bibliographie de l'histoire du Québec et du Canada, 1946-1965. Québec, Institut québécois de recherche sur la culture, 1987. Tomes 1 et 2.] Revue d'histoire de l'Amérique française, 41(2), 287-287. https://doi.org/10.7202/304573ar d'utilisation que vous pouvez consulter en ligne. 


\title{
NOTES BIOBLIOGRAPHIQUES
}

\author{
AUBIN, Paul et Louis-Marie COTÉ, Bibliographie de l'histoire du Québec et \\ du Canada, 1946-1965. Québec, Institut québécois de recherche sur la \\ culture, 1987. Tomes 1 et 2 .
}

Nous avons le plaisir de signaler à nos lecteurs la publication d'une nouvelle tranche de la Bibliographie de l'histoire du Québec et du Canada, celle répertoriant les titres parus entre 1946 et 1965 . Grâce aux volumes qui ont déjà vu le jour (voir $R H A F, 38,3$ (hiver 1985): 449-450; 39,3 (hiver 1986): 439440), ceux et celles qui s'intéressent à l'histoire canadienne et québécoise pourront retrouver facilement les livres, articles et thèses dont ils ont besoin pour la période 1946-1980.

L'organisation de ce nouveau volume, en deux tomes, est la même que celle des volumes précédents. Les titres se retrouvent donc sous trois rubriques: un classement systématique (avec des divisions thématiques), un classement analytique (utilisant des mots-clés), et un classement par auteur. Pour les articles, on a dépouillé plus de 400 périodiques. Quant aux livres, Canadiana et Bibliographie du Québec ont fourni la majeure partie des titres. Les divers répertoires de thèses ont également été mis à profit.

L'utilité du nouveau volume est d'autant plus grande que la bibliographie de la $R H A F$, très appréciée des chercheurs, s'est mise en branle en 1967 seulement.

Département d' histoire

Université Laval

RICHARD JONES 